\title{
ANTICOAGULATION BEFORE AND AFTER CARDIOVERSION OR ABLATION. CHALLENGES, PROBLEMS AND MISTAKES
}

\author{
Agnè Česnauskaitė, Andrius Montrimas, Diana Rinkūnienė, Aras Puodžiukynas \\ Lithuanian University of Health Sciences, Kaunas, Lithuania
}

Keywords: novel oral anticoagulants, electrical cardioversion, radiofrequency ablation, atrial fibrillation, atrial flutter.

\begin{abstract}
Summary
Background: Limited data exists addressing the daily use of anticoagulants for atrial fibrillation (AF) and atrial flutter (AFL) patients before and after electrical cardioversion (ECV) or catheter ablation procedures. The purpose of the study was to evaluate the appropriateness of anticoagulant therapy.

Methods: We evaluated the prescribed dosage of anticoagulant therapy for 257 non-valvular AF and AFL patients scheduled for ECV or catheter ablation and the appropriateness of periprocedural anticoagulation according to European Society of Cardiology (ESC) AF Guidelines. The statistical analysis was performed using IBM SPSS Statistics software (v.26.0).

Results: The majority of the patients (84\%) used nonvitamin $\mathrm{K}$ antagonist oral anticoagulants (NOACs) for pre-procedural anticoagulation. An intervention was not performed for $12.2 \%$ of warfarin users because of insufficient hypocoagulation, while anamnesis of patients' missed doses with a possibility of inadequate hypocoagulation occurred only in $1.9 \%$ of patients on NOACs. The odds of having insufficient pre-procedural hypocoagulation were 7.4 times higher for warfarin users compared to the NOACs group ( $\mathrm{p}=0.001, \mathrm{OR}=7.4)$. An incorrect NOAC dose was assigned to $22(8.6 \%)$ patients. Rivaroxaban was the most prescribed NOAC and this group of patients had the highest percentage of incorrect dosage according to the ESC guidelines.

Conclusions: Mistakes of prescribing the dosage of anticoagulant therapy are common. The majority of the patients in the study were prescribed with NOACs before and after ECV or catheter ablation procedures. Warfarin users had higher odds of the intervention not being performed and not reaching sufficient hypocoagulation prior to the procedure compared to NOACs users.
\end{abstract}

\section{Introduction}

It is generally known that AFL and AF patients have an increased risk of stroke, hence it is very important to administer anticoagulant therapy according to standard recommendations $[1,2]$. Since warfarin (vitamin K antagonist) was approved in 1954 for medical use in the United States, it has been the main and only available anticoagulant for the prevention of thromboembolism. The dominance of warfarin use as the only oral anticoagulant has changed when the first NOAC - dabigatran - was approved for the prevention of venous thromboembolism $[3,4]$. Even though warfarin is one of the safest and most effective medicines in the health system according to the World Health Organisation's List of Essential Medicines, a tendency can be seen that since NOACs have been introduced, the use of warfarin for the prevention of stroke and systemic embolism has been rapidly decreasing as the usage of NOACs increased [5-12]. Since the use of NOACs increases with time, it is important to understand limitations related with pharmacological properties of these drugs. As NOACs do not require regular monitoring, the problem of compliance arises $[13,14]$. Moreover, clinicians need to take into consideration the age, weight, renal function, and used medication of the patient when selecting the dose of NOACs as well as the $\mathrm{CHA}_{2} \mathrm{DS}_{2} \mathrm{VAS}_{\mathrm{c}}$ score. Prescription mistakes and failure to adhere to the guidelines are common $[13,15-19]$. There is evidence suggesting that the aforementioned factors may lead to an increased risk of bleeding or insufficient prevention of stroke $[13,16,17,19$ 22]. We decided to analyse real world data about the use of anticoagulants for AF and AFL patients before and after ECV or catheter ablation procedures in our hospital.

Main objectives were to evaluate the appropriateness of the dosage of the prescribed anticoagulant therapy prior to and after the intervention as well as to analyse the reasons why the scheduled procedure was not performed.

\section{Methods}

Study population. Retrospective study included 257 patients who have been admitted to Lithuanian University 
of Health Sciences Kauno Klinikos for elective non-valvular AF or AFL treatment in 2018. The patients were divided into two groups according to the required intervention: the first group underwent an ECV, and the second one had catheter ablation (RFA for AFL or RFA for AF) performed.

Evaluation methods. All the patients before and after the intervention were on oral anticoagulation. The $\mathrm{CHA}_{2} \mathrm{DS}_{2} \mathrm{VAS}_{\mathrm{c}}$ score was calculated in all patients. The doses of anticoagulant therapy before and after the intervention were evaluated according to the ESC AF guidelines (2016) [23]. An insufficient hypocoagulation for warfarin users was estimated in the following cases: if at least one INR value was below 2 or there was no data about INR

Table 1. Baseline characteristics of the study population

$E C V$-electrocardioversion, $R F A$ - radiofrequency ablation, $\mathrm{CrCl}$ - creatinine clearance, $B M I-b o d y$ mass index, AFL - atrial flutter, AF - atrial fibrillation, INR - International Normalised Ratio (for blood clotting time)

* (mean $( \pm S D))$

**p value for ECV patients versus catheter ablation

\begin{tabular}{|c|c|c|c|c|}
\hline Variable & $\begin{array}{l}\text { All patients } \\
(n=257)\end{array}$ & $\begin{array}{c}\text { ECV } \\
(n=97)\end{array}$ & $\begin{array}{c}\text { RFA } \\
(n=160)\end{array}$ & p value** \\
\hline Gender (male, \%) & $173(67.3)$ & $61(62.9)$ & $112(70.7)$ & 0.239 \\
\hline Age* & $65.2( \pm 11.7)$ & $64.8( \pm 10.7)$ & $65.4( \pm 12.4)$ & 0.713 \\
\hline $\mathrm{CrCl}(\mathrm{ml} / \mathrm{min})^{*}$ & $80.9( \pm 32.7)$ & $86.3( \pm 32.6)$ & $78.0( \pm 32.5)$ & 0.068 \\
\hline $\mathrm{CrCl}>80 \mathrm{ml} / \mathrm{min}(\%)$ & $100(43.3)$ & $40(50.6)$ & $60(39.5)$ & 0.104 \\
\hline INR* & $1.7( \pm 0.8)$ & $1.9( \pm 1.1)$ & $1.6( \pm 0.7)$ & 0.196 \\
\hline Haemoglobin $(\mathrm{g} / \mathrm{l})^{*}$ & $138.7( \pm 15.7)$ & $141.3( \pm 15.2)$ & $137.2( \pm 15.9)$ & 0.086 \\
\hline $\operatorname{BMI}\left(\mathrm{kg} / \mathrm{m}^{2}\right)^{*}$ & $29.4( \pm 5.5)$ & $30.3( \pm 5.7)$ & $28.9( \pm 5.4)$ & 0.061 \\
\hline $\mathrm{CHA}_{2} \mathrm{DS}_{2}-\mathrm{VAS}_{\mathrm{C}} *$ & $2.8( \pm 1.4)$ & $2.7( \pm 1.3)$ & $2.9( \pm 1.5)$ & 0.351 \\
\hline - $>=2(\%)$ & $198(78.3)$ & $77(80.2)$ & $121(77.1)$ & 0.557 \\
\hline
\end{tabular}

Table 2. Baseline characteristics of the study population by used anticoagulation therapy

$N O A C s$ - novel oral anticoagulants, $\mathrm{Cr} C l$-creatinine clearance, $B M I$ - body mass index, ECV-electrocardioversion, RFA for AFL - radiofrequency ablation for atrial flutter, RFA for AF- radio radiofrequency ablation for atrial fibrillation, INR - International Normalised Ratio (for blood clotting time) *(mean ( $\pm S D)$ )

\begin{tabular}{|c|c|c|c|}
\hline Variable & $\begin{array}{c}\text { Warfarin users } \\
(n=41)\end{array}$ & $\begin{array}{c}\text { NOACs users } \\
(n=216)\end{array}$ & p value \\
\hline Gender (male, \%) & $28(68.3)$ & $145(67.1)$ & 0.884 \\
\hline Age* & $67.3( \pm 10.0)$ & $64.7( \pm 12.0)$ & 0.199 \\
\hline $\mathrm{CrCl}(\mathrm{ml} / \mathrm{min})^{*}$ & $71.0( \pm 31.7)$ & $82.7( \pm 32.6)$ & 0.045 \\
\hline $\mathrm{CrCl}>80 \mathrm{ml} / \mathrm{min}(\%)$ & $11(29.7)$ & $89(45.9)$ & 0.069 \\
\hline Haemoglobin $(\mathrm{g} / \mathrm{l}) *$ & $133.2( \pm 16.3)$ & $139.8( \pm 15.5)$ & 0.031 \\
\hline BMI $\left(\mathrm{kg} / \mathrm{m}^{2}\right)^{*}$ & $29.9( \pm 6.4)$ & $29.4( \pm 5.3)$ & 0.603 \\
\hline $\mathrm{ECV}(\%)$ & $11(26.8)$ & $86(39.8)$ & 0.114 \\
\hline RFA for AFL (\%) & $27(65.9)$ & $104(48.1)$ & 0.114 \\
\hline RFA for AF (\%) & $3(7.3)$ & $26(12.0)$ & 0.114 \\
\hline $\mathrm{CHA}_{2} \mathrm{DS}_{2}-\mathrm{VAS}_{\mathrm{C}} *$ & $3.3( \pm 1.4)$ & $2.7( \pm 1.4)$ & 0.025 \\
\hline Maximum value & 6 & 7 & \\
\hline - $\quad>=2(\%)$ & $36(87.8)$ & $162(76.4)$ & 0.106 \\
\hline
\end{tabular}

testing performed weekly for 4 weeks, For NOAC users - in the case of a missed dose and/or less than 3 weeks of pre-procedural anticoagulation. Patients with insufficient hypocoagulation underwent transoesophageal echocardiography (TEE), and if thrombus in left atrium appendage was not found, the intervention was performed. Creatinine clearance $(\mathrm{CrCl})$ was evaluated using the Cockcroft-Gault (CG) equation: $\mathrm{CrCl}=((140-$ age $(\mathrm{yr})) *$ weight $(\mathrm{kg}) *$ sex (to be multiplied by 1.04 for women or 1.23 for men) $) /($ serum creatinine $(\mu \mathrm{mol} / 1))[24]$. NOACs doses were assessed according to age, weight, renal function and concomitant medication [25].

Statistical analysis. Statistical analysis was performed by IBM SPSS Statistics version 26 software, $p$ value less than 0,05 was considered statistically significant. Oneway ANOVA test was used to describe baseline characteristics and compare the means of scale variables, crosstabs were used to calculate the odds ratio as well as to compare nominal variables, the chi-square test was used to evaluate whether differences between the variables were statistically significant. The study was performed with the permission of Kaunas Regional Biomedical Research Ethics Committee, ref. No. BE-2-48, and an informed consent was obtained from each patient.

\section{Results}

A total of 257 patients were included in the study. The patients were predominantly male $(67.3 \%)$, mean age $65.2 \pm 11.7$ years, mean $\mathrm{CHA}_{2} \mathrm{DS}_{2}-\mathrm{VAS}_{\mathrm{C}}$ score $2.8 \pm 1.4$ (78.3\% of patients had $\mathrm{CHA}_{2} \mathrm{DS}_{2}-\mathrm{VAS}_{\mathrm{C}}$ score $\geq 2$ ) (Table 1). The number of the patients with AFL or AF was similar and $16 \%$ of all patients used warfarin for preprocedural anticoagulation (Table 2). In catheter ablation group, $18.1 \%$ of the patients had AF and were admitted for RFA, these patients were significantly younger, with a better renal function and a lower thromboembolic risk (mean $\mathrm{CHA}_{2} \mathrm{DS}_{2}-$ VAS $_{\mathrm{C}} 2.1 \pm 1.6$ ). 
Anticoagulation and renal function. The majority of patients (84\%) used NOACs for pre-procedural anticoagulation. Patients on NOAC's had statistically significantly better renal function, higher hemoglobin values and lower mean $\mathrm{CHA}_{2} \mathrm{DS}_{2}-\mathrm{VAS}_{\mathrm{C}}$ score compared to warfarin users (Table 2). The prevalence of renal dysfunction $(\mathrm{CrCl} \leq 80 \mathrm{ml} /$ min) among all patients was $56.7 \%$ with $12.6 \%$ of patients with at least moderate renal impairment $(\mathrm{CrCl}<50 \mathrm{ml} / \mathrm{min})$. Patients with an impaired renal function were statistically significantly older, had higher $\mathrm{CHA}_{2} \mathrm{DS}_{2}-\mathrm{VAS}_{\mathrm{C}}$ mean score, lower BMI and haemoglobin levels, furthermore, they used warfarin for anticoagulation more frequently compared to patients with a normal renal function.

Anticoagulant selection, dose regimen for elective interventions. The only reason why an intervention was not performed for warfarin users was insufficient hypocoagulation, which was observed in $12.2 \%$ of patients, while anamnesis of patients' missed doses with a possibility of inadequate hypocoagulation occurred only in $1.9 \%$ of patients on NOACs. The odds of having inadequate pre-procedural hypocoagulation were 7.4 times higher for warfarin users compared to NOACs group ( $\mathrm{p}=0.001, \mathrm{OR}=7.4$ ).

Rivaroxaban was the most frequently used NOAC (58.8\%) compared to apixaban (35.1\%) and dabigatran $(5.1 \%)$ in our patient population. Incorrect NOAC dose on discharge according to the ESC guidelines [23] was recommended to $22(8.6 \%)$ patients. The highest percentage of incorrect dosage was found in the rivaroxaban group (Table 3).

\section{Discussion}

Even though NOACs are preferable to warfarin, they still have limitations and require proper dose selection for every individual patient $[16,17,26]$. Since NOACs are eliminated through the kidneys, they can accumulate as the renal function gets worse and therefore the risk of bleeding increases. Additionally, chronic kidney disease (CKD) is an independent risk factor for bleeding events along with thromboembolism related to AF[20,27-30]. Despite the fact that CKD-EPI equation for estimated glomerular filtration rate (eGFR) is widely used in the classification and staging of CKD, when prescribing higher risk drugs such as anticoagulants, it is highly recommended to use Cockroft-Gault (CG) equation to calculate $\mathrm{CrCl}$ [31]. Since one of the main aims of our study was to evaluate the prescribed dosage of NOACs, we used the CG equation to assess the renal function and found that $56.7 \%$ of our patients had impaired renal function $(\mathrm{CrCl}$ $\leq 80 \mathrm{ml} / \mathrm{min}$ ) with $12.6 \%$ of patients having moderate-severe renal impairment $(\mathrm{CrCl}<50 \mathrm{ml} / \mathrm{min})$. Other studies used $\mathrm{CG}$ to evaluate renal function as well. Hawkins et al published the data of 559 AF patients where the prevalence of impaired renal function was $63.3 \%$ and a quarter $(27.9 \%)$ of all patients had at least moderate renal impairment [32]. The study that included $2398 \mathrm{AF}$ patients found a lower presence of CKD in AF patients, a total of $55.1 \%$ of patients had CKD with $18.5 \%$ of the studied population having moderate-severe renal function impairment [33]. Meanwhile, 3 out 4 patients who are newly prescribed with NOACs in the UK primary care are over 65 years old [11]. As the risk of developing chronic kidney CKD increases with age, there is a big probability that a significant number of patients prescribed with NOACs might need an adjusted dose, hence it is very important to evaluate the $\mathrm{CrCl}$ before selecting the dose of NOACs. However, automatic laboratory reports usually present renal function according to CKD-EPI equation, so this value could be used and as a consequence, mistakes when prescribing the dosage of NOACs are possible. Some clinicians may also evaluate renal function only by the value of serum creatinine concentration and may not take into consideration that $\mathrm{CrCl}$ varies depending on gender and age, included in the CG equation [26].

Various studies reflect the incidence of mistakes when prescribing the dosage of NOACs. High volume study included 30467 patients initiating NOACs with non-valvular AF, where $23.1 \%$ of the patients were prescribed with an inappropriate dosage of NOACs accordingly: $15.8 \%$ of patients on rivaroxaban, $25.1 \%$ on apixaban and $25.6 \%$ on dabigatran [16]. Contrary to this study, we have observed the largest percentage of mistakes in the group of patients using rivaroxaban (11.3\% of patients). The percentage of incorrect dosage varies between different studies from all over the world. Another large study from the USA included 7925 patients with AF and found that the dosage of NOACs was inappropriate for $4 \%$ of patients who received a standard

Table 3. Evaluation of the dosage of NOACs according to the ESC guidelines [23]

$E C V$-electrocardioversion, $R F A$ - radiofrequency ablation

*p value for ECV patients versus catheter ablation patients

\begin{tabular}{|l|c|c|c|c|}
\hline Variable & $\begin{array}{c}\text { All patients } \\
\mathbf{n = 2 5 7}(\mathbf{\%})\end{array}$ & $\begin{array}{c}\text { ECV } \\
\mathbf{n = 9 7}(\mathbf{9})\end{array}$ & $\begin{array}{c}\text { RFA } \\
\mathbf{n = 1 6 0}(\mathbf{\%})\end{array}$ & p value* \\
\hline Patients discharged with rivaroxaban & $151(58.8)$ & $61(62.9)$ & $90(56.3)$ & 0.295 \\
\hline$\bullet$ Incorrect dosage of rivaroxaban & $17(11.3)$ & $4(6.6)$ & $13(14.4)$ & 0.132 \\
\hline Patients discharged with apixaban & $53(20.6)$ & $17(17.5)$ & $36(22.5)$ & 0.339 \\
\hline$\bullet$ Incorrect dosage of apixaban & $4(7.5)$ & $0(0)$ & $4(11.1)$ & 0.153 \\
\hline Patients discharged with dabigatran & $13(5.1)$ & $7(7.2)$ & $6(3.8)$ & 0.219 \\
\hline$\bullet$ Incorrect dosage of dabigatran & $1(7.7)$ & $0(0)$ & $1(16.7)$ & 0.261 \\
\hline
\end{tabular}


dose and for $57 \%$ of patients who received a reduced dose [22]. Several studies regarding this topic were performed in the Netherlands: the first one included 3231 patients from Martini Hospital electronic information system, the other one collected data from the Dutch subset of the XANTUS registry (899 patients) and observed label-discordant dosage of NOACs in $10.7 \%$ and $8.3 \%$ of patients respectively $[17,34]$. Even though the reasons for the different incidence of incorrect dosage between various countries and hospitals are not known, it can be seen that inappropriate dosing is common, especially when it comes to underdosing. In contrast to different studies, we observed a prevalence of $8.6 \%$ of incorrect dosage of NOACs in our research with no significant differences between the patients who underwent ECV or catheter ablation.

Moreover, adherence to the recommendations of anticoagulant therapy in our studied population of patients is essential not only to prevent stroke, but also to maintain sufficient hypocoagulation which is crucial for the intervention to be performed. We evaluated the patients' persistence with NOACs therapy before the procedure and found that only $1.9 \%$ of them had missed a dose or the duration of their anticoagulant use was too short. Since the indicated duration of NOAC therapy before ECV or catheter ablation procedures is only 3 weeks, this could be the reason why we observed such a low percentage of patients not adhering to the therapy prescribed. In contrast, $12.2 \%$ of warfarin users in our studied population had insufficient pre-procedural hypocoagulation and therefore could not undergo an intervention. Thus, using warfarin in order to keep sufficient preprocedural hypocoagulation can be challenging due to the fact that maintaining regular INR levels is difficult, whereas dose monitoring as well as dose adjustment is substantial.

This study has several limitations. First of all, this was a retrospective analysis of clinical records. Moreover, a small degree of mistakes could have been made in calculation of $\mathrm{CrCl}$ since practitioners sometimes file only the approximate weight of the patients. Additionally, patients' laboratory tests came from different laboratories, which somewhat could have influenced the results. Furthermore, this study was conducted in a single centre, thus there are certain limitations to adapt these findings to the general population.

\section{Conclusions}

Mistakes of prescribing the dosage of anticoagulant therapy are still common. The majority of the patients in the study were prescribed NOACs before and after ECV or catheter ablation procedures. Warfarin users had higher odds of the intervention not being performed as well as not reaching sufficient hypocoagulation prior to the procedure when compared to NOACs users. Rivaroxaban was prescribed to more than half of the patients prior to and after the procedure and at the same time this group of patients had the highest percentage of incorrect dosage according to the ESC guidelines.

\section{References}

1. Lin YS, Chen YL, Chen TH, Lin MS, Liu CH, Yang TY, et al. Comparison of clinical outcomes among patients with atrial fibrillation or atrial flutter stratified by CHA2DS2-VASc score. JAMA 2018;1(4):e180941.

https://doi.org/10.1001/jamanetworkopen.2018.0941

2. Wolf PA, Abbott RD, Kannel WB. Atrial fibrillation as an independent risk factor for stroke: the Framingham Study. 2014. https://doi.org/10.1161/01.STR.22.8.983

3. Pradaxa. European medicines agency. https:/www.ema.europa. eu/en/medicines/human/EPAR/pradaxa\#overview-section

4. Drug Approval Package: Pradaxa (dabigatran etexilate mesylate) NDA \#022512. https://www.accessdata.fda.gov/drugsatfda_ docs/nda/2010/022512Orig1s000TOC.cfm

5. WHO model lists of essential medicines. WHO 2020. https:// www.who.int/medicines/publications/essentialmedicines/en/

6. Desai NR, Krumme AA, Schneeweiss S, Shrank WH, Brill G, Pezalla EJ, et al. Patterns of initiation of oral anticoagulants in patients with atrial fibrillation - quality and cost implications. Am J Med 2014;127(11):1075-1082.e1. https://doi.org/10.1016/j.amjmed.2014.05.013

7. Zhu J, Alexander GC, Nazarian S, Segal JB, Wu AW. Trends and variation in oral anticoagulant choice in patients with atrial fibrillation, 2010-2017. Pharmacotherapy 2018;38(9):907-20. https://doi.org/10.1016/j.jval.2018.04.389

8. Yu AYX, Malo S, Svenson LW, Wilton SB, Hill MD. Temporal trends in the use and comparative effectiveness of direct oral anticoagulant agents versus warfarin for nonvalvular atrial fibrillation: a Canadian population-based study. J Am Heart Assoc 2017;6(11):e007129. https://doi.org/10.1161/JAHA.117.007129

9. Kirley K, Qato DM, Kornfield R, Stafford RS, Caleb Alexander G. National trends in oral anticoagulant use in the United States, 2007 to 2011. Circ Cardiovasc Qual Outcomes 2012;5(5):615-21.

https://doi.org/10.1161/CIRCOUTCOMES.112.967299

10. Maura G, Billionnet C, Drouin J, Weill A, Neumann A, Pariente A. Oral anticoagulation therapy use in patients with atrial fibrillation after the introduction of non-vitamin $\mathrm{K}$ antagonist oral anticoagulants: Findings from the French healthcare databases, 2011-2016. BMJ Publishing Group 2019;9. https://doi.org/10.1136/bmjopen-2018-026645

11. Loo SY, Dell'Aniello S, Huiart L, Renoux C. Trends in the prescription of novel oral anticoagulants in UK primary care. Br J Clin Pharmacol 2017;83(9):2096-106. 
https://doi.org/10.1111/bcp.13299

12. Staerk L, Fosbøl EL, Gadsbøll K, Sindet-Pedersen C, Pallisgaard JL, Lamberts $\mathrm{M}$, et al. Non-vitamin K antagonist oral anticoagulation usage according to age among patients with atrial fibrillation: temporal trends 2011-2015 in Denmark. Sci Rep 2016:6.

https://doi.org/10.1038/srep31477

13. Lowres N, Giskes K, Hespe C, Freedman B. Reducing stroke risk in atrial fibrillation: adherence to guidelines has improved, but patient persistence with anticoagulant therapy remains suboptimal. Korean Circ J 2019;49(10):883-907. https://doi.org/10.4070/kcj.2019.0234

14. Raparelli V, Cangemi R, Lane DA, Proietti M, Basili S, Lip GYH. Adherence to oral anticoagulant therapy in patients with atrial fibrillation. Thromb Haemost 2016;117(02):209-18. https://doi.org/10.1160/TH16-10-0757

15. GPnotebook shortcut - direct oral anticoagulant (DOAC) dosing for stroke prevention shortcuts in those with non-valvular atrial fibrillation - General Practice Notebook. https://gpnotebook. com/simplepage.cfm?ID $=x 20190111172649437326 \&$ fbclid $=$ IwAR3wL35Dyd-a1Z507oUCcEXP6NECMVwnnfN8uix95 2s6mX7CZsGxniPZOyI

16. Rodríguez LAG, Martín-Pérez M, Vora P, Roberts L, Balabanova Y, Brobert G, et al. Appropriateness of initial dose of non-vitamin $\mathrm{K}$ antagonist oral anticoagulants in patients with non-valvular atrial fibrillation in the UK. BMJ Open 2019;9(9). https://doi.org/10.1136/bmjopen-2019-031341

17. Jacobs MS, van Hulst M, Campmans Z, Tieleman RG. Inappropriate non-vitamin $\mathrm{K}$ antagonist oral anticoagulants prescriptions: be cautious with dose reductions. Netherlands Hear J 2019;27(7-8):371-7. https://doi.org/10.1007/s12471-019-1267-9

18. Whitworth MM, Haase KK, Fike DS, Bharadwaj RM, Young RB, MacLaughlin EJ. Utilization and prescribing patterns of direct oral anticoagulants. Int J Gen Med 2017;10:87-94. https://doi.org/10.2147/IJGM.S129235

19. Kim WJ, Park JM, Kang K, Cho YJ, Hong KS, Lee SJ, et al. Adherence to guidelines for antithrombotic therapy in patients with atrial fibrillation according to CHADS2 score before and after stroke: A multicenter observational study from Korea. J Clin Neurol 2016;12(1):34-41. https://doi.org/10.3988/jen.2016.12.1.34

20. Tran H, Joseph J, Young L, McRae S, Curnow J, Nandurkar H, et al. New oral anticoagulants: a practical guide on prescription, laboratory testing and peri-procedural/bleeding management. Intern Med J 2014;44(6):525-36. https://doi.org/10.1111/imj.12448

21. Singer DE, O'Brien EC, Peterson ED, Piccini JP, Piccini JP. Factors associated with non-vitamin $\mathrm{K}$ antagonist oral anticoagulants for stroke prevention in patients with new-onset atrial fibrillation: Results from the outcomes registry for better informed treatment of atrial fibrillation II (ORBIT-AF II). Am
Heart J 2017;189:40-7.

https://doi.org/10.1016/j.ahj.2017.03.024

22. Steinberg BA, Shrader P, Pieper K, Thomas L, Allen LA, Ansell $\mathrm{J}$, et al. Frequency and outcomes of reduced dose Non-vitamin $\mathrm{K}$ antagonist anticoagulants: results from ORBIT-AF II (The outcomes registry for better informed treatment of atrial fibrillation II). J Am Heart Assoc 2018;7(4).

https://doi.org/10.1161/JAHA.117.007633

23. Atrial Fibrillation (management of) ESC Guidelines. https:// www.escardio.org/Guidelines/Clinical-Practice-Guidelines/ Atrial-Fibrillation-Management

24. Florkowski CM, Chew-Harris JSC. Methods of estimating GFR - Different equations including CKD-EPI. Clinical Biochemist Reviews 2011;32:75-9. https://www.ncbi.nlm.nih. gov/pubmed/21611080

25. Pharmacokinetics in patients with impaired renal function-study design, data analysis, and impact on dosing and labeling. Guidance document. FDA 1998. http://www.fda.gov/cder/ guidance/index.htmor http:/www.fda.gov/cber/guidelines.htm

26. Howard M, Lipshutz A, Roess B, Hawes E, Deyo Z, Burkhart JI, et al. Identification of risk factors for inappropriate and suboptimal initiation of direct oral anticoagulants. J Thromb Thrombolysis 2017;43(2):149-56. https://doi.org/10.1007/s11239-016-1435-3

27. Stamellou E, Floege J. Novel oral anticoagulants in patients with chronic kidney disease and atrial fibrillation. Nephrology Dialysis Transplantation 2018;33(10):1683-1689. https:// doi.org/10.1093/ndt/gfx322

28. Marinigh R, Lane DA, Lip GYH. Severe renal impairment and stroke prevention in atrial fibrillation: implications for thromboprophylaxis and bleeding risk. Journal of the American College of Cardiology. Elsevier USA 2011;57:1339-48.

https://doi.org/10.1016/j.jacc.2010.12.013

29. Go AS, Fang MC, Udaltsova N, Chang Y, Pomernacki NK, Borowsky L, et al. Impact of proteinuria and glomerular filtration rate on risk of thromboembolism in atrial fibrillation. Circulation 2009;119(10):1363-9. https://doi.org/10.1161/CIRCULATIONAHA.108.816082

30. Reinecke H, Brand E, Mesters R, Schäbitz WR, Fisher M, Pavenstädt $\mathrm{H}$, et al. Dilemmas in the management of atrial fibrillation in chronic kidney disease. Journal of the American Society of Nephrology 2009;20:705-11.

https://doi.org/10.1681/ASN.2007111207

31. British Medical Association, Royal Pharmaceutical Society of Great Britain, Joint Formulary Committee (Great Britain). BNF 76 :2018 - 2019. https://www.medicinescomplete.com/\#/

32. Hawkins NM, Jhund PS, Pozzi A, O'Meara E, Solomon SD, Granger CB, et al. Severity of renal impairment in patients with heart failure and atrial fibrillation: implications for non-vitamin $\mathrm{K}$ antagonist oral anticoagulant dose adjustment. Eur J Heart Fail 2016;18(9):1162-71.

https://doi.org/10.1002/ejhf.614 
33. Boriani G, Laroche C, Diemberger I, Popescu MI, Rasmussen LH, Petrescu L, et al. Glomerular filtration rate in patients with atrial fibrillation and 1-year outcomes. Sci Rep 2016;6. https://doi.org/10.1038/srep30271

34. Pisters R, Van Vugt SPG, Brouwer MA, Elvan A, Ten Holt WL, Zwart PAG, et al. Real-life use of rivaroxaban in the Netherlands: Data from the xarelto for prevention of stroke in patients with atrial fibrillation (XANTUS) registry. Netherlands Hear J 2017;25(10):551-8.

https://doi.org/10.1007/s12471-017-1009-9

\section{ANTIKOAGULIANTU VARTOJIMAS PRIEŠ IR PO ELEKTRINĖS KARDIOVERSIJOS AR RADIODAŽNINĖS ABLIACIJOS. IŠŠŪKIAI, PROBLEMOS, KLAIDOS \\ A. Česnauskaitè, A. Montrimas, D. Rinkūnienè, \\ A. Puodžiukynas}

Raktažodžiai: naujieji antikoaguliantai, elektrinė kardioversija, radiodažninè abliacija, prieširdžių virpejjimas, prieširdžių plazdèjimas.

Santrauka

Yra nedaug tyrimų, nagrinèjančių prieširdžių virpėjimu (PV) ar plazdejjimu (PP) sergančių pacientų kasdienį antikoaguliantų vartojimą prieš ir po elektrinès kardioversijos (EKV) ar radiodažninès abliacijos (RDA). Šio tyrimo tikslas - įvertinti antikoaguliantų vartojimo ypatumus minètomis aplinkybèmis. Tyrimo metu įvertinta
257 nevožtuvinės kilmės PV ar PP sergančių pacientų, kuriems atlikta EKV arba RDA, vartojama antikoaguliantų dozė ir jos atitikimas Europos kardiologų draugijos PV rekomendacijas. Statistinė analizė atlikta naudojantis IBM SPSS Statistics programine įranga (v.26.0). Nustatyta, kad dauguma pacientų ( 84 proc.) vartojo naujuosius antikoaguliantus prieš atliekamą procedūrą. EKV arba RDA nebuvo atliktos 12,2 proc. varfarino vartotojų dèl nepakankamos hipokoaguliacijos, kai tik 1,9 proc. naujujų antikoaguliantų vartotojų sakè praleidę vieną ar kelias dozes, traktuojant tai kaip galimą nepakankamą hipokoaguliaciją. Nepakankamos hipokoaguliacijos tikimybè buvo 7,4 kartus didesnè varfarino vartotojams, lyginant juos su naujujų antikoaguliantų vartotojais $(\mathrm{p}=0,001$; $\mathrm{OR}=7,4)$. Netinkama naujųjų antikoaguliantų dozė buvo paskirta 22 (8,6 proc.) pacientams. Rivaroksabanas buvo dažniausiai skiriamas naujasis antikoaguliantas. Jị vartojančių pacientų grupei dažniausiai buvo paskiriama netinkama dozè, lyginant su vartojančiais apiksabaną ar dabigatraną.

Antikoaguliantų dozavimo klaidos yra dažnos. Didžiajai daliai pacientų buvo paskirti naujieji antikoaguliantai po EKV ar RDA. Varfarino vartotojams buvo didesnè tikimybè, jog jiems nebus atlikta intervencija, ar jie nepasieks pakankamos hipokoaguliacijos prieš procedūrą, lyginant su naujųjų antikoaguliantų vartotojais.

Adresas susirašinèti: diana.rinkuniene@1smuni.lt

Gauta 2020-11-06 